\title{
EVALUASI PRESTASI BELAJAR MAHASISWA TERHADAP PERILAKU BELAJAR DAN MOTIVASI BELAJAR MAHASISWA DI PERGURUAN TINGGI KOTA PADANG PROVINSI SUMATERA BARAT
}

\author{
Prima Yulianti, Mellyna Eka Yan Fitri \\ Universitas Dharma Andalas \\ Fakultas Ekonomi dan Bisnis \\ Jl. Sawahan No. 103 A, Simpang Haru Padang \\ Email: prima.unidha@gmail.com
}

\begin{abstract}
Abstrak
Mahasiswa sebagai input suatu perguruan tinggi mempunyai sikap dan penilaian terhadap proses belajar-mengajar yang berbeda antara satu dengan yang lain. Perbedaan ini adalah sebagai akibat dari adanya perbedaan pengalaman personal, latar belakang keluarga, maupun budaya. Hal ini tergambar dalam perilaku belajar mahasiswa tersebut. Penelitian ini bertujuan ini untuk mengetahui pengaruh perilaku belajar dan motivasi belajar terhadap prestasi belajar mahasiswa. Populasi yang diambil adalah mahasiswa aktif yang dari perguruan tinggi di kota Padang. Sampel dengan teknik Incidental Sampling berjumlah 358 mahasiswa/i. Hasil yang diperoleh adalah terdapatnya hubungan perilaku belajar dan motivasi belajar terhadap prestasi belajar pada tingkat signifikan 5\%. Dan diperoleh tiga faktor untuk perilaku belajar yaitu faktor kemandirian dalam pembelajaran, fokus pada minat belajar dan adanya faktor penghambat motivasi yang harus diatasi. Selanjutnya diperoleh tiga faktor motivasi belajar yaitu metode belajar, strategi belajar dan keterampilan dalam belajar. Terakhir adalah merancang strategi untuk meningkatkan prestasi belajar mahasiswa dalam bentuk analisis SWOT.
\end{abstract}

Kata kunci: Perilaku belajar, motivasi belajar, prestasi belajar, strategi belajar

\begin{abstract}
The college students as an input in university have different attitudes and different assessments on teachinglearning process from one to another. This is due to differences in personal experience, family background, and culture. This is reflected in the students learning and motivation behavior.Population of the study are active student and sample was taken from several public universities and several private universities in Padang, West Sumatera. The sample was taken about 358 students. This study aims to determine the effect of learning behavior and learning motivation on student achievement, establish the factors of learning behavior and learning motivation that must be considered in order to increase student achievement.The Results of this study found that learning behavior and learning motivation influence student achievement at the significance level 5\%. The other analysis obtained three factors for learning behavior (the process factors in learning, encouragement in learning and skills in Learning) and the three factors for motivation learning (diligence in learning, focus on interest in learning and learning inhibitors of motivation. This study also design a strategy to improve the achievement of student.
\end{abstract}

Keywords: learning behavior, learning motivation, learning achievement, learning strategies

\section{Pendahuluan}

Sumber daya manusia sebagai salah satu sumber daya terpenting yang dapat mengelola dan mengatur sumber daya lainnya. Sumber daya manusia yang terbentuk dipengaruhi oleh beberapa faktor yang salah satunya adalah faktor pendidikan. Dengan adanya pendidikan yang baik maka terbentuklah sumber daya manusia yang terdidik dan berkualitas. Untuk meningkatkan kualitas sumber daya manusia melalui pendidikan perlu ditingkatkan yaitu dengan pengembangan institusi pendidikan baik melalui pelajar, pengajar atau pun sarana dan prasarana pendidikan.

Ketiga hal tersebut harus mampu berkolaborasi sehingga pendidikan yang dihasilkan sesuai dengan yang diharapkan yaitu menghasilkan sumber daya manusia yang berprestasi. Harapan ini tentunya 
dijawab oleh dunia kerja yang menginginkan lulusan berkualitas dan terdidik serta siap untuk berpartisipasi. Fenomena kualitas belajar di perguruan tinggi seringkali dipertanyakan dalam hal mencetak tenaga yang profesional, apakah mampu menjawab kebutuhan dunia kerja.

Kenyataannya para lulusan perguruan tinggi banyak mengalami perbedaan pandangan dan pemahaman dalam hal dunia kerja. Masalah yang sering ditemui adalah mahasiswa kurang memiliki keterampilan dan kreativitas dalam hal implementasi ilmu pengetahuan yang diperolehnya di perguruan tinggi untuk diterapkan pada dunia kerja. Akibatnya lulusan yang berprestasi belajar yang baik pun tidak mampu berkecimpung di dunia kerja.

Mahasiswa sebagai input suatu perguruan tinggi mempunyai sikap dan penilaian terhadap proses belajar-mengajar yang berbeda antara satu dengan yang lain. Perbedaan ini adalah sebagai akibat dari adanya perbedaan pengalaman personal, latar belakang keluarga, maupun budaya. Hal ini tergambar dalam perilaku belajar mahasiswa tersebut.

Banyak hal dalam perilaku belajar yang dapat mempengaruhi proses belajar mahasiswa. Seorang mahasiswa mampu mengikuti perkuliahan tanpa memiliki buku panduan dan catatan perkuliahan, namun terdapat mahasiswa lainnya yang tidak mampu mengikuti perkuliahan tanpa memiliki buku panduan. Selain itu, seorang mahasiswa memiliki rasa tanggung jawab dalam menyelesaikan tugastugas perkuliahan secara mandiri. Namun ada mahasiswa lainnya yang membutuhkan diskusi dalam penyelesaian tugas-tugas perkuliahan.

Selain itu, fenomena yang sering terjadi adalah mahasiswa sangat tegantung kepada para dosen sebatas materi yang diberikan dalam perkuliahan. Jarang ditemukan mahasiswa yang berusaha mencari referensi dan materi perkuliahan secara mandiri. Semua yang diberikan dosen, hanya itu yang mereka terima. Model perkuliahan yang dibawakan oleh dosen seringkali juga mempengaruhi pemahaman mahasiswa terhadap materi perkuliahan.

Dari segi motivasi belajar antara satu mahasiswa dengan mahasiswa lainnya akan berbeda. Menurut Stephen P. Robbins bahwa "Motivasi merupakan kesediaan individu untuk mengeluarkan upaya yang tinggi untuk mencapai organisasi." Sedangkan menurut Slameto (2013) bahwa "Belajar adalah suatu proses usaha yang dilakukan seseorang untuk memperoleh suatu perubahan tingkah laku yang baru secara keseluruhan, sebagai hasil pengalamannya sendiri dalam interaksi dengan lingkungannya." Jadi motivasi belajar adalah kesediaan mahasiswa atau pelajar dalam mengeluarkan upaya yang tinggi untuk suatu perubahan tingkah laku yang baru sebagai hasil pengalamannya sendiri dengan lingkungannya dan guna memperoleh prestasi yang baik.

Motivasi belajar dapat dipengaruhi dari dalam diri mahasiswa itu sendiri atau pun dari luar diri mahasiswa tersebut. Mahasiswa yang kuliah karena dorongan diri sendiri dan dorongan orang tua akan menghasilkan prestasi yang berbeda. Apapun yang dilakukan, motivasi merupakan salah satu hal utama yang harus diperhatikan agar memperoleh hasil yang sesuai harapan.

Dosen sebagai pendidik harus mampu menemukan cara yang tepat untuk memotivasi mahasiswa agar belajar sebaik mungkin. Menurut Brophy (1998) dalam Sudaryono dan Bharata (2004) menyatakan bahwa "Pendidik harus membantu siswanya untuk menghargai nilai dari kegiatan-kegiatan sekolah dan memastikan bahwa siswa dapat mencapai keberhasilan dalam kegiatankegiatan tersebut." Sebaik apapun tenaga pengajar dan fasilitas pendidikan yang disediakan, siswa tidak akan berprestasi jika tidak memiliki motivasi belajar.

Selain itu, perguruan tinggi sebagai salah satu kunci utama yang dapat memotivasi mahasiswa untuk menghasilkan prestasi yang baik, maka berupaya memberikan stimulan untuk mengajarkan, menumbuhkan, dan mengembangkan potensi yang dimiliki oleh setiap mahasiswa agar dapat mewujudkan prestasi atau kinerja yang optimal.

Berdasarkan permasalahan tersebut, maka peneliti memiliki tujuan dalam hal sebagai berikut: Mengetahuipengaruh perilaku belajar dan motivasi belajar terhadap prestasi belajar (2)

Mengidentifikasi faktor-faktor perilaku belajar dan motivasi belajar mahasiswa yang harus diperhatikan agar prestasi belajar mahasiswa, (3) Menyusun strategi dalam meningkatkan prestasi belajar mahasiswa melalui perilaku belajar dan motivasi belajar mahasiswa pada perguruan tinggi di Kota Padang Provinsi Sumatera Barat.

\section{Kajian Pustaka Prestasi Belajar}

Prestasi dalam bahasa Inggris yaitu kata achievement yang berasal dari kata to achieve yang berarti mencapai. Menurut Kamus Besar Bahasa Indonesia (2014) bahwa "Prestasi adalah hasil yang telah dicapai”. Jadi, prestasi merupakan hasil usaha yang telah dicapai seseorang atas hal yang dilakukan pada suatu kegiatan. Prestasi bisa dilihat dari berbagai segi misalnya pekerjaan dan pembelajaran.

Belajar menurut Kamus Besar Bahasa Indonesia memiliki (2014) tiga arti, yakni berusaha memperoleh kepandaian atau ilmu, berlatih dan berubahnya tingkah laku atau tanggapan yang disebabkan oleh pengalaman. Selanjutnyamenurut Arnold N dalam Slameto (2010) bahwa "Belajar adalah suatu proses usaha yang dilakukan seseorang untuk memperoleh suatu perubahan tingkah laku yang baru secara keseluruhan sebagai hasil 
pengalamannya sendiri dalam interaksi dengan lingkungannya."

Sedangkan menurut Dimyati dan Mujiono (2006) bahwa "Prestasi belajar merupakan hasil dari suatu interaksi tindak belajar dan tindak mengajar." Jadi, dapat disimpulkan bahwa prestasi belajar adalah hasil yang diperoleh seseorang setelah melakukan pembelajaran melalui suatu penilaian dalam kurun waktu tertentu.

\section{Perilaku Belajar}

Kegiatan belajar mengajar di perguruan tinggi tidak hanya perkuliahan di kelas saja, akan tetapi juga meliputi diskusi, seminar, dan praktikum. Dalam kegiatan ini terjadi interaksi langsung antara mahasiswa dan dosen yang memungkinkan mahasiswa menangkap astusiasme dosen dalam menjelaskan suatu topik. Selanjutnya, mahasiswa dapat langsung bertanya apabila ada sesuatu hal yang belum dimengerti. Dalam hal ini disebut perilaku belajar mahasiswa dalam merespon pembelajaran.

Menurut Kamus Besar Bahasa Indonesia bahwa "Perilaku adalah tanggapan atau reaksi individu terhadap rangsangan atau lingkungan." Selanjutnya, menurut Walgito (2010) bahwa "Perilaku adalah suatu aktivitas yang mengalami perubahan dalam diri individu." Perubahan itu didapat dalam segi kognitif, afektif dan psikomotorik. Sedangkan menurut (Notoatmodjo, 2010) bahwa "Perilaku adalah semua tindakan atau aktivitas dari manusia itu sendiri yang mempunyai bentangan yang sangat luas, baik yang dapat diamati langsung atau pun tidak dapat diamati." Jadi, perilaku adalah semua tindakan sebagai respon terhadap rangsangan atau lingkungan sehingga mengalami perubahan dalam diri individu tersebut.

Perilaku belajar yang efektif dapat membantu seseorang dalam meningkatkan kemampuannya sesuai dengan harapan yang dituju. Adapun hal-hal yang perlu diperhatikan adalah kondisi internal dari dalam diri mahasiswa, kondisi eksternal dari luar diri mahasiswa, strategi belajar seperti keadaan jasmani, emosional dan sosial, lingkungan, mulai belajar, membagi pekerjaan, pengendalian, waktu belajar dan jangan membaca belaka (Slameto, 2010). Selanjutnya adalah metode belajar yaitu pembuatan jadwal dan pelaksanaannya, membaca dan membuat catatan, mengulangi bahan pelajaran, konsentrasi dan mengerjakan tugas (Slameto, 2010).

\section{Motivasi Belajar}

Kata motivasi berasal dari bahasa Latin yaitu movere yang berarti "menggerakkan". Menurut Kamus Besar Bahasa Indonesia (KBBI) bahwa "Motivasi adalah dorongan yang timbul pada diri seseorang secara sadar atau tidak untuk melakukan suatu tindakan dengan tujuan tertentu." Menurut Robbins (2015) bahwa "Motivasi adalah proses yang menjelaskan mengenai kekuatan, arah dan ketekunan seseorang dalam upaya untuk mencapai tujuan. Sedangkan menurut Griffin (2013) bahwa "Motivasi adalah serangkaian kekuatan yang mengakibatkan orang-orang berprilaku dengan cara tertentu." Jadi, motivasi adalah dorongan yang timbul dari diri seseorang yang menyebabkan terjadinya perubahan untuk mencapai tujuan, kebutuhan dan keinginan. Dalam pembelajaran, motivasi pun dibutuhkan yaitu motivasi untuk mencapai tujuan pembelajaran.

Menurut Astuti (2010) bahwa "Motivasi belajar adalah sesuatu yang mendorong, menggerakkan dan mengarahkan siswa dalam belajar. Motivasi belajar yang tinggi akan tercermin dalam ketekunan untuk mencapai kesuksesan dan mampu mengatasi semua kesulitan yang dihadapi selama pembelajaran. Bila pengajar membangkitkan motivasi belajar anak didik, maka mereka akan memperkuat respon yang telah dipelajarinya. (Tim Pengembang Ilmu Pendidikan FIP-UPI, 2007).

\section{Perencanaan Strategi Prestasi Belajar}

Menurut Suwarsono (2010) bahwa tujuan menerapkan manajemen stratejik adalah untuk meningkatkan keberhasilan manajemen dengan meningkatkan peluang bisnis sebagai faktor eksternal dan mengurangi kelemahan sebagai faktor internal. Perencanaan strategik untuk meningkatkan prestasi belajar mahasiswa dipengaruhi oleh faktor internal dan faktor eksternal. Faktor internal terdiri dari faktor yang berasal dari dalam diri mahasiswa itu sendiri sedangkan faktor eksternal terdiri dari faktor yang berasal dari luar diri mahasiswa yang dapat mempengaruhi prestasi belajarnya. Faktor internal meliputi strategi belajar, perilaku belajar, motivasi belajar serta pengaturan diri, sedangkan faktor eksternal meliputi kurikulum, materi ajar, dosen, buku panduan, jadwal perkuliahan dan sarana serta prasarana.

\section{Kerangka Pemikiran}

Penelitian ini dilakukan dalam lingkup manajemen sumber daya manusia dan pendidikan. Penelitian ini ditujukan kepada mahasiswa dalam meningkatkan prestasi belajar melalui perilaku belajar dan motivasi belajar mahasiswa. Keterbatasan dalam memberikan pemahaman kepada perilaku belajar dan motivasi belajar sering menyebabkan kurangnya upaya untuk meningkatkan prestasi belajar mahasiswa. Penelitian ini ditujukan kepada mahasiswa perguruan tinggi di Kota Padang Provinsi Sumatera Barat mengenai peningkatan prestasi belajar melalui perilaku belajar dan motivasi belajar.

Adapun kerangka Pemikiran dari penelitian ini pada Gambar 1, sebagai berikut: 


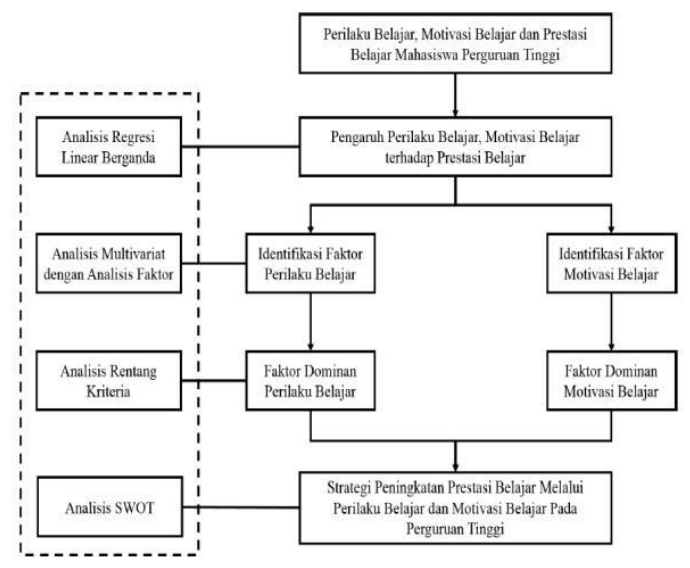

Gambar 1. Kerangka Pemikiran Penelitian

\section{Hipotesis Penelitian}

Berdasarkan tinjauan pustaka yang telah diuraikan sebelumnya, maka peneliti menduga bahwa perilaku belajar dan motivasi belajar berpengaruh terhadap prestasi belajar mahasiswa di Perguruan Tinggi Kota Padang Sumatera Barat.

\section{Metode Penelitian}

\section{Lokasi dan Waktu Penelitian}

Penelitian ini dilaksanakan pada mahasiswa perguruan tinggi di Kota Padang Provinsi Sumatera Barat. yaitu empat perguruan tinggi negeri dan empat perguruan tinggi swasta pada semester genap 2016/2017 bulan Mei, Juni dan bulan Juli tahun 2017.

\section{Populasi penelitian}

Populasi yang digunakan dalam penelitian ini adalah mahasiswa dari perguruan tinggi negeri dan swasta di Kota Padang Sumatera Barat yang memiliki jenjang pendidikan Strata 1 dan Diploma 3 di perguruan tinggi tersebut.

\section{Sampel Penelitian}

Sampel yang diambil dengan teknik pengambilan sampel kluster yang dilakukan dengan beberapa tahap lalu dilanjutkan dengan Incidental Sampling. Incidental Sampling adalah teknik penentuan sampel berdasarkan kebetulan, yaitu siapa saja yang secara kebetulan/insidental bertemu dengan peneliti dapat digunakan sebagai sampel, bila dipandang orang yang kebetulan ditemui itu cocok dengan sumber data (Sugiyono, 2012)

Penelitian ini dilaksanakan pada mahasiswa perguruan tinggi baik swasta ataupun negeri yang ada di Kota Padang Sumatera Barat. Dengan alasan bahwa adanya perubahan prestasi belajar mahasiswa jika adanya perubahan perilaku belajar dan motivasi belajar mahasiswa tersebut. Selanjutnya Kota Padang adalah pusat pendidikan yang memiliki perguruan tinggi terbanyak dibanding kota lainnya di Sumatera Barat.
Pengambilan sampel sebanyak 50 responden untuk tiap perguruan tinggi yang ada di Kota Padang, yaitu (1) Universitas Islam Negeri, (2) Universitas Andalas, (3) Universitas Negeri Padang, (4) Universitas Bung Hatta, (5) Universitas Eka Sakti, (6) Universitas Putra Indonesia, (7) Stkip PGRI Sumbar, Poltekkes Kemenkes RI Padang, sehingga diperoleh 400 responden namun hanya sekitar 358 responden yang memenuhi kriteria, sedangkan sisanya tidak memenuhi syarat untuk bisa diolah datanya.

\section{Variabel Penelitian}

Variabel-variabel penelitian yang digunakan dalam penelitian ini adalah variabel perilaku belajar dan motivasi belajar sebagai variabel bebas sedangkan variabel prestasi belajar sebagai variabel terikat.

Tabel 1. Operasional Variabel

\begin{tabular}{|c|c|c|}
\hline $\begin{array}{l}\text { Nama } \\
\text { Variabel }\end{array}$ & Penjelasan & Skala Pengukuran \\
\hline $\begin{array}{l}\text { Perilaku } \\
\text { belajar }\end{array}$ & $\begin{array}{lr}\text { Suatu tindakan } & \text { mental } \\
\text { dan psikis } & \text { yang } \\
\text { berlangsung } & \text { dalam } \\
\text { interaksi aktif dengan } & \text { dingkungan yang } \\
\text { menghasilkan } & \\
\text { perubahan-perubahan } \\
\text { dalam pengetahuan, } \\
\text { pemahaman, } \\
\text { keterampilan dan nilai } \\
\text { sikap }\end{array}$ & Skala Likert \\
\hline $\begin{array}{l}\text { Motivasi } \\
\text { belajar }\end{array}$ & $\begin{array}{l}\text { Motivasi belajar adalah } \\
\text { sesuatu yang mendorong, } \\
\text { menggerakkan dan } \\
\text { mengarahkan siswa } \\
\text { dalam belajar }\end{array}$ & Skala Likert \\
\hline $\begin{array}{l}\text { Prestasi } \\
\text { belajar }\end{array}$ & 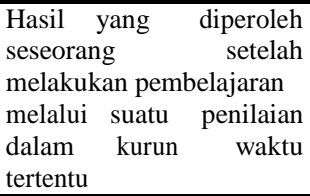 & Skala Likert \\
\hline
\end{tabular}

\section{Rancangan Penelitian}

Jenis penelitian ini adalah penelitian survey kuantitatif. Sampel yang dipilih adalah mahasiswa yang sudah memiliki IPK yaitu minimal semester dua. Setiap mahasiswa yang dipilih diberikan kuisioner untuk memperoleh informasi mengenai perilaku belajar dan motivasi belajar yang selanjutnya ditemukan faktor-faktor perilaku belajar dan motivasi belajar yang dapat mendorong prestasi belajar mahasiswa.

\section{Pelaksanaan Penelitian}

Pelaksanaan penelitian terdiri atas beberapa tahap, yaitu mengumpulkan data terdiri dari membuat kuisioner sebagai instrumen penelitian, menyebarkan kuisioner untuk mendapatkan informasi dari mahasiswa. Selanjutnya adalah pengolahan data yaitu melakukan pengujian validitas dan reliabilitas instrumen dan melakukan analisis data sebagai berikut : 
1. Melakukan pengujian validitas dan reliabilitas instrumen.

2. Melakukan analisis data penelitian yaitu dengan metode sebagai berikut :

a. Uji asumsi klasik regresi untuk faktorfaktor yang dihasilkan.

b. Analisis regresi untuk mengetahui pengaruh perilaku belajar dan motivasi belajar terhadap terhadap prestasi belajar mahasiswa.

c. Analisis multivariat analisis faktor untuk mengidentifikasi

faktor-faktor perilaku belajar dan motivasi belajar yang mendukung prestasi belajar mahasiswa.

d. Analisis SWOT untuk rancangan strategi peningkatan prestasi belajar mahasiswa melalui perilaku belajar dan motivasi belajar.

3. Selanjutnya, penafsiran hasil analisis yang dapat digunakan untuk rekomendasi dalam meningkatkan prestasi belajar mahasiswa melalui perilaku belajar dan motivasi belajar mahasiswa.

\section{Hasil dan Pembahasan}

\section{Analisis Karakteristik Responden}

Responden yang dipilih dalam penelitian ini adalah mahasiswa yang sudah memiliki IPK yang berasal dari beberapa perguruan tinggi yang terpilih di Kota Padang. Adapun karakteristik responden yang dipilih adalah beragam baik dari segi gender, usia, tingkatan perkuliahan, serta IPK.

\section{Karakteristik Responden berdasarkan Gender dan IPK}

Hasil survey yang dilakukan, tercatat sejumlah 358 responden yang ikut berpartisipasi mewakili jumlah populasi mahasiswa di kota Padang. Dari 358 responden diperoleh rentang IPK mahasiswa pada tabel 1 berikut ini :

Tabel 2. Karakteristik Responden berdasarkan Gender dan

\begin{tabular}{llllll}
\multicolumn{7}{c}{ IPK } \\
\hline No. & Gender & $\begin{array}{l}\text { IPK } \\
<2.75\end{array}$ & $\begin{array}{l}\text { IPK 2.75 } \\
-3.5\end{array}$ & IPK > 3.5 & Total \\
\hline 1 & Laki-laki & 6 & 100 & 43 & 149 \\
\hline 2 & Perempuan & 11 & 118 & 80 & 209 \\
\hline Total & & 17 & 218 & 123 & 358
\end{tabular}

Sumber: Hasil Pengolahan Data SPSS 20, 2017

Diperoleh bahwa IPK mahasiswa berkisar antara 2.75 - 3.5 adalah sebanyak 218 mahasiswa atau sekitar $60.89 \%$ yang terdiri dari 100 mahasiswa dan 118 mahasiswi. Perilaku belajar dan motivasi belajar saat ini yang dimiliki mahasiswa memberikan hasil yang baik. Hal ini dibuktikan oleh nilai IPK mahasiswa/i yang lebih banyak bekisar pada grade $2.75-3.5$.

\section{Karakteristik Responden Berdasarkan Gender dan Jenjang Pendidikan}

Hasil survey yang dilakukan dari 358 responden yang mewakili populasi mahasiswa di kota Padang, maka diperoleh hasil pada tabel 2 berikut ini:

Tabel 3. Karakteristik Responden berdasarkan Gender dan

\begin{tabular}{|c|c|c|c|c|}
\hline No. & Gender & Diploma & $\begin{array}{l}\text { Sarjana } \\
\text { Strata } 1 \\
\end{array}$ & Total \\
\hline 1 & Laki-laki & 9 & 139 & 148 \\
\hline 2 & Perempuan & 41 & 169 & 210 \\
\hline Total & & 50 & 308 & 358 \\
\hline
\end{tabular}

Diperoleh bahwa sekitar $84,92 \%$ responden adalah sarjana S1 atau sekitar 304 responden dan sisanya adalah diploma. Hasil penelitian ini memperlihatkan kondisi perilaku belajar dan motivasi belajar mayoritas mahaiswa/i sarjana Strata 1 yang pada umumnya lebih lama setahun untuk berada di perguruan tinggi dibandingkan diploma. Sehingga akan tergambarkan bagaimana perilaku belajar dan motivasi belajar yang sudah terbentuk.

\section{Karakteristik Responden berdasarkan Jenjang Pendidikan dan Tingkatan Perkuliahan}

Dari survey yang dilakukan bahwa 358 responden yang mewakili populasi mahasiswa di kota Padang, maka diperoleh hasil pada tabel 3 berikut ini :

Tabel 4. Karakteristik Responden berdasarkan Jenjang

\begin{tabular}{lllllll}
\multicolumn{7}{c}{ Pendidikan Tingkatan Perkuliahan } \\
\hline No. & Jenjang & Tahun & Tahun & Tahun & Tahun & Total \\
\hline 1 & Pendidikan & 1 & 2 & 3 & 4 & 50 \\
\hline 2 & Diploma & 3 & & 44 & 3 & 308 \\
\hline Total & & 51 & 106 & 160 & 41 & 358 \\
\hline
\end{tabular}

Sumber: Hasil Pengolahan Data SPSS 20, 2017

Diperoleh bahwa sekitar 86,04\% atau 308 mahasiswa/i adalah mahasiswa sarjana Strata 1 dengan jumlah mahasiswa tahun ketiga lebih banyak terpilih yaitu sekitar $32,40 \%$ atau 116 mahasiswa/i. Hal ini menunjukkan bahwa prilaku belajar yang terbentuk lebih cenderung mahasiswa yang lebih lama berkuliah di perguruan tinggi, tentu mendukung penelitian yang akan dilakukan yaitu mengetahui perngaruh perilaku belajar yang selama ini mereka lakukan dan motivasi belajar yang sudah terbentuk selama diperkuliahan terhadap prestasi belajar mahasiswa.

\section{Uji Hipotesis \\ Uji Simultan (Uji F)}

Uji simultan digunakan untuk mengetahui pengaruh perilaku belajar dan motivasi belajar 
terhadap prestasi belajar mahasiswa secara bersamasama. Diperoleh hasil pada tabel 8 yaitu nilai signifikansi sebesar 0,000 kurang dari nilai taraf signifikansi yang dipilih yaitu 5\%. Artinya bahwa terdapat pengaruh perilaku belajar dan motivasi belajar secara bersamaan terhadap prestasi belajar. Hal ini dapat dilihat pada tabel berikut.

Tabel 5. Uji Pengaruh Perilaku Belajar dan Motivasi Belajar secara Simultan terhadap Prestasi Belajar ANUVA $^{\circ}$

\begin{tabular}{|l|r|r|r|r|r|}
\hline Model & Sum of Squares & df & Mean Square & F & \multicolumn{1}{|c|}{ Sig. } \\
\hline Regression & 28,146 & 2 & 14,073 & 488,044 &, 0006 \\
1 & 10,237 & 355 &, 029 & & \\
Residual & 38,383 & 357 & & & \\
Total & & & & & \\
\hline
\end{tabular}

a. Dependent Variable: $Y$

b. Predictors: (Constant), X2, X1

\section{Uji Parsial (Uji t)}

Uji parsial digunakan untuk mengetahui apakah ada pengauh perilaku belajar dan motivasi belajar terhadap prestasi belajar mahasiswa. Dalam hal ini tabel 9 daat mengetahui nilai signifikansi koefisien regresi yang dihasilkan. Dengan tingkat signifikansi yang dipilih 5\% diperoleh bahwa terdapatnya pengaruh yang signifikan antara perilaku belajar dan motivasi belajar terhadap prestasi belajar secara parsial.

Tabel 6. Uji Pengaruh Perilaku Belajar dan Motivasi Belajar secara Parsial terhadap Prestasi Belajar

\section{Coefficients}

\begin{tabular}{|c|c|c|c|c|c|c|c|}
\hline \multirow[t]{2}{*}{ Model } & \multicolumn{2}{|c|}{$\begin{array}{l}\text { Unstandardized } \\
\text { Coefficients }\end{array}$} & \multirow{2}{*}{\begin{tabular}{|c|}
$\begin{array}{c}\text { Standardized } \\
\text { Coefficients }\end{array}$ \\
Beta
\end{tabular}} & \multirow[t]{2}{*}{$t$} & \multirow[t]{2}{*}{ Sig. } & \multicolumn{2}{|c|}{ Collinearity Statistics } \\
\hline & $B$ & Sto. Error & & & & Tolerance & VF \\
\hline (Constant) &, 014 &, 089 & & 6,936 &, 000 & & \\
\hline$X 1$ &, 097 &, 028 &, 108 & 3,441 &, 001 &, 757 & 1,321 \\
\hline$X 2$ & 704 &, 028 &, 798 & 25,315 &, 000 &, 757 & 1,321 \\
\hline
\end{tabular}

\section{a. Dependent Variable: $Y$}

Dari tabel 9 di atas diperoleh bahwa terdapat pengaruh positif perilaku belajar terhadap prestasi belajar artinya prestasi belajar akan naik sekitar 9,7\% apabila perilaku belajar meningkat sekitar $100 \%$ tanpa adanya motivasi belajar. Selain daripada itu bahwa terdapat pengaruh positif motivasi belajar terhadap prestasi belajar artinya prestasi belajar akan naik sekitar $70,4 \%$ apabila motivasi belajar meningkat sekitar $100 \%$ tanpa adanya prestasi belajar.

\section{Koefisien Determinasi $\left(\mathbf{R}^{2}\right)$}

Koefisien determinasi digunakan untuk mengetahui berapa persentase variabel terikat dapat dijelaskan oleh variasi variabel bebas. Nilai ini berada antara 0 hingga 1 . Bila mendekati 0 berarti sedikit sekali variasi variabel terikat yang diterangkan oleh variabel bebas. Jika nilai mendekati 1 berarti semakin banyak variasi variabel terikat yang dapat diterangkan oleh variabel bebas. Dalam hal ini pada tabel 10 diperoleh nilai koefisien determinasi sebesar 0,733 Artinya bahwa sekitar 73,3\% variasi perilaku belajar dan motivasi belajar dapat menjelaskan variasi prestasi belajar mahasiswa, sedangkan sisanya sebesar 26,7\% dipengaruhi oleh variasi faktor lainnya.

Tabel 7. Uji Koefisien Determinasi

Model Summarri ${ }^{b}$

\begin{tabular}{|c|c|c|c|c|c|}
\hline Model & $R$ & RSquare & $\begin{array}{c}\text { Adusted R } \\
\text { Square }\end{array}$ & \begin{tabular}{|c|} 
Sidd. Error of the \\
Estinate
\end{tabular} & Dubinin.Walson \\
\hline 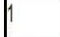 & $850^{8}$ & 7733 &, 732 & 16981. & 1,69 \\
\hline
\end{tabular}

a. Predictors: (Constant), X2, X1

b. Dependent Variabe: $Y$

\section{Analisis Faktor \\ Analisis Kelayakan Data}

Untuk mengetahui faktor-faktor perilaku belajar dan motivasi belajar mahasiswa perguruan tinggi di Kota Padang maka digunakan analisis faktor metode komponen utama. Sebelum analisis faktor dilakukan, item-item yang akan digunakan harus memiliki korelasi antar sesamanya. Jika terpenuhi maka analisis faktor tepat digunakan. Pengujian dilakukan untuk dua item variabel bebas yaitu item perilaku belajar dan item motivasi belajar. Analisis multivariat dengan analisis faktor dapat dilakukan jika langkah pertama dalam pengujian kelayakan data terpenuhi. Hal ini diuji dengan Nilai KMO dan uji Bartlet yang dapat dilihat pada tabel 7 berikut ini :

\begin{tabular}{|c|c|c|c|}
\hline \multicolumn{3}{|l|}{ Perilaku } & Motivasi \\
\hline $\begin{array}{l}\text { Kaiser-Meyer-Ol } \\
\text { Sampling Adequa }\end{array}$ & $\begin{array}{l}\text { n Measure of } \\
\text { y. }\end{array}$ & ,754 & ,758 \\
\hline \multirow{3}{*}{$\begin{array}{l}\text { Bartlett's Test of } \\
\text { Sphericity }\end{array}$} & $\begin{array}{l}\text { Approx. Chi- } \\
\text { Square }\end{array}$ & 535,409 & 627,17 \\
\hline & $\mathrm{df}$ & 45 & 45 \\
\hline & Sig. & ,000 & ,000 \\
\hline
\end{tabular}

Sumber : Hasil Pengolahan Data SPSS 20, 2017

Dari tabel 7 di atas diperoleh bahwa angka KMO sebesar 0,754 untuk perilaku belajar serta 0,758 untuk motivasi belajar dan hasil koreksi Bartlett dengan tingkat signifikansi 0,000 yang jauh dibawah 0,05 mengindikasikan bahwa data tepat digunakan dalam analisis faktor.

\section{Penentuan Banyak Faktor dan Pengelompokkan Variabel}

Penentuan banyak faktor dilakukan dengan menggunakan nilai eigen dari masing-masing item. 
Hal ini dapat dijelaskan melalui Total Variance Explained masing-masing variabel. Dan diperoleh hasil bahwa 3 faktor untuk perilaku belajar terbentuk dengan nilai variansi sekitar 52,647\%. Artinya bahwa sekitar 52,647\% variansi dari variabel mulamula dapat dijelaskan oleh tiga faktor tersebut. Hal ini merupakan angka yang baik dan dapat diwakili oleh ketiga faktor tersebut.

\section{Pengelompokkan variabel-variabel ke dalam Faktor-Faktor}

Hasil SPSS metode ekstraksi yang digunakan untuk pembagian variabel adalah principal component factoring analysis. Pembagian variabelvariabel ke dalam kelompok faktor tertentu didasarkan pada perbandingan nilai loading faktor secara mutlak mana yang lebih besar. Untuk variabel perilaku belajar diperoleh faktor-faktor sebagai berikut:

1. Faktor 1, metode belajar yang merupakan suatu cara yang diimplementasikan mahasiswa dalam proses pembelajaran. Adapun faktor-faktor tersebut didukung oleh beberapa pernyataan yang sudah ditanyakan kepada mahasiswa yang bersangkutan, yaitu
a) Membuat catatan atau pertanyaan pada setiap mata kuliah yang diajarkan
b) Membaca buku teks sebelum mengikuti perkuliahan
c) Membaca catatan yang dibuat sewaktu mengikuti perkuliahan
d) Jam belajar menjadi lebih banyak sebelum mengikuti ujian
e) Memusatkan perhatian kepada materi di kelas

2. Faktor 2, strategi belajar yang merupakan langkah-langkah tindakan yang mendasar dan berperan besar dalam proses pembelajaran untuk mencapai sasaran. Adapun faktor-faktor tersebut didukung oleh:

a) teks lain selain yang diminta dosen

b) Menyempatkan berkunjung ke perpustakaan secara teratur

c) Sering berlatih mengerjakan soalsoal

3. Faktor 3, keterampilan dalam pembelajaran yang merupakan suatu keterampilan yang dapat mengembangkan kemandirian mahasiswa untuk belajar. Adapun faktorfaktor tersebut didukung oleh:

a. Sering meminta penjelasan ke dosen jika ada yang kurang jelas

b. Sering memberi tanda pada bagian penting atas materi yang dibaca dari buku
Untuk variabel motivasi belajar diperoleh faktor-faktor sebagai berikut:

1. Faktor 1, kemandirian dalam pembelajaran yang merupakan kemandirian mahasiswa untuk dapat mengambil inisiatif dengan atau tanpa bantuan orang lain dalam hal pembelajaran. Adapun faktor-faktor tersebut didukung oleh :

a) Mencari informasi yang berhubungan dengan mata kuliah

b) Berusaha dalam belajar walaupun tahu tidak mendapatkan prestasi yang baik

c) Pantang menyerah dalam menyelesaikan tugas-tugas kuliah

d) Keyakinan akan mampu memperbaiki nilai yang kurang agar lebih baik lagi

e) Membuat jadwal kegiatan di rumah agar dapat mengetahui waktu yang pas untuk belajar

f) Berusaha untuk menemukan alternatif pemecahan jika menghadapi kesulitan dalam mempelajari mata kuliah

2. Faktor 2, fokus pada minat belajar yang merupakan perhatian dan rasa suka mahasiswa serta ketertarikan tehadap proses belajar yang dijalaninya dan kemudian ditunjukkan melalui partisipasi dan antusias dalam mengikuti proses pembelajaran. Adapun faktor-faktor tersebut didukung oleh :

a) Rajin mengahadiri perkuliahan yang disukai

b) Hadir tepat waktu ketika belajar pada mata kuliah yang dianggap lebih mudah

3. Faktor 3, penghambat motivasi yang merupakan faktor negatif yang pasti ada dalam diri mahasiswa. Namun hal ini bisa menjadi pertimbangan bagi mahasiswa, dosen dan keluarga agar pembelajaran tetap berjalan sesuai sasaran. Adapun faktor-faktor tersebut didukung oleh:

a) Merasa putus asa bila menghadapi kesulitan dalam mempelajari mata kuliah

b) Menghabiskanbanyak waktu untuk mengikuti kegiatan organisasi

\section{Pembahasan Hasil Olah Data}

Dari hasil olah data yang sudah dilakukan, terdapat pengaruh perilaku belajar dan motivasi belajar terhadap prestasi belajar. Motivasi belajar adalah hal yang paling penting untuk diperhatikan. Hal ini didukung dari hasil pengujian dengan koefisien regresi lebih tinggi dibandingkan perilaku belajar. Yaitu sekitar 70,4\%, artinya jika motivasi belajar $100 \%$ meningkatk maka prestasi belajar 70,4\% meningkat juga. Sehingga motivasi belajar harus diperhatikan baik oleh mahasiswa, dosen dan lingkungan keluarga.

Adapun faktor-faktor penting yang terkait motivasi belajar adalah kemandirian dalam pembelajaran, fokus pada minat belajar dan adanya faktor penghambat motivasi yang harus diatasi. 
Faktor penghambat ini selanjutnya akan diberikan alternatif atau pertimbangan bagi mahasiswa, dosen dan keluarga agar dapat meningkatkan motivasi belajar.

Untuk perilaku belajar juga mempengauhi prestasi belajar sebesar $9,7 \%$ artinya jika perilaku belajar $100 \%$ diperbaiki menjadi lebih baik akan meningkatkan prestasi belajar sekitar $9,7 \%$ dari sebelumnya. Perilaku belajar ini lebih dominan dimiliki oleh mahasiswa, sedangkan dosen dan keluarga hanya mengarahkan dan membimbing mereka agar perilaku belajar lebih baik kedepannya. Adapun faktor-faktor penting dalam perilaku belajar adalah metode belajar, strategi belajar dan keterampilan dalam belajar.

Hal ini sejalan dengan penelitian yang dilakukan oleh Amrai dkk (2011) dalam The relationship between academic motivation and academic achievement students diperoleh bahwa terdapat hubungan yang positif dan signifikan antara motivasi belajar dengan prestasi belajar. Dalam hal ini prestasi belajar memerlukan koordinasi dan interaksi antara berbagai aspek motivasi, seperti usaha, persaingan dan kepedulian sosial. Sedangkan penelitian yang dilakukan oleh Rafiqah dkk (2013) diperoleh bahwa motivasi belajar berpengaruh signifikan terhadap prestasi belajar.

Begitu juga dengan penelitian yang dilakukan oleh Wulandari (2014) bahwa motivasi belajar, perilaku belajar dalam hal kebiasaan membaca buku teks dan kebiasaan mengikuti ujian, serta model pembelajaran konstruktivisme berpengaruh terhadap prestasi belajar mahasiswa.

\section{Hasil Analisis SWOT}

1. Kategori Perilaku Belajar

a. Strength

(Kekuatan) 1

Keterampilan

bahwa perilaku belajar mahasiswa berdasarkan hasil analisis keterampilan menunjukkan Srengthdengan nilai standar sembilan $([8+10] / 2=9)$.

2 Metode Belajar

bahwaperilakubelajarmahasiswa

berdasarkan analisis metode belajar menunjukkan Strength dengan nilai standar delapan $([8+8+8+8+8] / 5=8)$.

3 Strategi Belajar

bahwa perilaku belajar mahasiswa

berdasarkan analisis strategi belajar menunjukkan Strength dengan nilai standar delapan $([8+8+8] / 3=8)$.

b. Weakness (Kelemahan)

bahwa dari hasil analisis kategori perilaku belajar adanya kelemahan mahasiswa dalam belajar yaitu memaksakan diri menambah jam belajar saat menghadapi ujian.

\section{c. Opportunity (Kesempatan)}

bahwa dari hasil analisis kategori perilaku belajar menunjukkan adanya peluang untuk memperoleh prestasi yang baik yaitu dengan menyediakan buku-buku dan referensi belajar diperpustakaan serta menyajikan materi yang menarik dan mudah dipahami mahasiswa.

d. Threats (Ancaman)

bahwa perilaku belajar dari hasil analisis metode belajar adanya ancaman mahasiswa akan cepat merasa lelah dalam belajar, karena terlalu memaksakan diri menambah jam belajar saat menghadapi ujian. Selain daripada itu, adanya ancaman bahwa mahasiswa lain akan salah menggunakan catatan yang dipelajari selama perkuliahan, seperti melakukan kecurangan dengan melihat catatan saat ujian.

2. Kategori Motivasi Belajar

a. Strength (Kekuatan)

1. Minat Belajar

bahwa motivasi belajar mahasiswa berdasarkan analisis minat belajar menunjukkan Strength dengan nilai standar sepuluh $([10+10] / 2=10)$.

2. Kemandirian

bahwa motivasi belajar mahasiswa berdasarkan analisis kemandirian menunjukkan Strength dengan nilai standar delapan koma tiga ( $[10+8+8+8+8+8] / 6=8,33)$.

b. Weakness (Kelemahan)

bahwa dari hasil analisis motivasi terdapat kelemahan mahasiswa dalam belajar yaitu masih adanya mahasiswa yang merasa putus asa bila menghadapi kesulitan dalam menghadapi mata kuliah yang sulit.

c. Opportunity (Kesempatan)

bahwa motivasi belajar dari hasil analisis kemandirian menunjukkan adanya peluang untuk mengurangi rasa putus asa bila menghadapi kesulitan dalam menghadapi kuliah, yaitu dengan menemukan alternatif lain dalam pemecahan kesulitan tersebut dan mencari informasi seoptimal mungkin yang tekait dengan mata kuliah tersebut.

d. Threats (Ancaman)

bahwa motivasi belajar dari hasil analisis penghambat motivasi akan ada ancaman terganggunya perkuliahan mahasiswa karena keterlibatan mahasiswa dalam 
berorganisasi. Jika mahasiswa tidak mampu mengendalikan dan membatasi kegiatan organisasinya maka akan mengganggu prestasi belajar mahasiswa tersebut.

3. Kategori Prestasi Belajar

a. Strength

(Kekuatan)

1. Bakat

bahwa prestai belajar mahasiswa berdasarkan analisis bakat menunjukkan Strength dengan nilai skor delapan $([8+8] / 2$

$=8$ ).

2. Intelegensi

bahwa prestasi belajar mahasiswa berdasarkan analisis tingkat intelegensi atau kecerdasan menunjukkan Strength dengan nilai skor delapan $([8+8+8+8+8+8] / 6=8$ ).

3. Motivasi

bahwa prestasi belajar mahasiswa berdasarkan analisis motivasi belajar menunjukkan Strength dengan nilai skor sepuluh $([10+10] / 2=10)$.

b. Weakness (Kelemahan)' bahwa dari hasil analisis prestasi belajar tidak ada kelemahan mahasiswa yang ditemukan.

c. Opportunity (Kesempatan)

bahwa prestasi belajar dari hasil analisis bakat menunjukkan adanya peluang untuk meningkatkan prestasi belajar mahasiswa yaitu adanya keterampilan dan kemampuan mahasiswa dalam menggali bakat dan minatnya dalam belajar, sedangkan dalam tingkat kecerdasan memberikan peluang mahasiswa untuk mampu menyelesaikan perkuliahannya dengan tepat waktu.

d. Threats (Ancaman)

bahwa dari hasil analisis prestasi belajar mahasiswa adanya ancaman pada mahasiswa yang berprestasi diluar kampus yaitu akan lupa kewajibannya untuk menyelesaikan tugasnya di dalam kampus.

\section{Kesimpulan}

1. Terdapat pengaruh perilaku belajar dan motivasi belajar terhadap prestasi belajar mahasiswa perguruan tinggi di kota Padang.

2. Terdapat tiga faktor perilaku belajar yang berperan penting dalam mempengaruhi prestasi belajar pada mahasiswa perguruan tinggi di kota Padang, yaitukemandirian dalam pembelajaran, fokus pada minat belajar dan adanya faktor penghambat motivasi yang harus diatasi.

3. Terdapat tiga faktor motivasi belajar yang berpern penting dalam mempengaruhi prestasi belajar pada mahasiswa perguruan tinggi di kota Padang, yaitu metode belajar, strategi belajar dan kemandirian dalam belajar.

4. Dari penyusunan strategi dalam meningkatkan prestasi belajar dengan menggunakan analisis SWOT, dapat disimpulkan bahwa standar nilai tertinggi terletak pada kekuatan yaitu motivasi belajar mahasiswa berdasarkan minat belajar, setelah itu pada kategori prestasi belajar terletak pada motivasi belajar mahasiswa.

\section{Saran}

Adapun saran yang dapat diberikan adalah mengetahui faktor-faktor perilaku belajar dan motivasi belajar mahasiswa yang dapat meningkatkan prestasi belajar mahasiswa. Seperti hal-hal kemandirian dalam pembelajaran apakah dia menyadari pentingnya belajar sehingga seain di kelas, mereka pun mencari informasi terkait pembelajaran secara mandiri. Selain daripada itu, mengidentifikasi hal yang menjadi fokus minat belajar mahasiswa. Selain daripada itu mengidentifikasi strategi yang dapat menunjang kegiatan belajar mahasiswa seperti membuat jadwal pelajaran diluar kelas, mengulangi pelajaran di rumah, menggaris bawahi catatan utama, membuat catatan pinggiran dan lain-lain. Selanjutnya dalam hal keterampilan belajar yaitu keterampilan dalam teknik mencatat sehingga mengingat pelajaran dengan cepat, keterampilan mengatai kejenuhan dalam belajar, keterampilan cara mengatur waktu, keterampilan dalam membaca sehingga tidak membosankan, dan lain-lain.

\section{REFERENSI}

A.M, Sardiman. 2006. Interaksi dan Motivasi Belajar Mengajar. Jakarta: Rajawali Pers.

Amrai, Kourosh, dkk. 2011. The Relationhip Between

Academic Motivation and Academic Achievement Students, Procedia Social and Behavioral Science, 15 (2011) : 399-402

Dahar, Ratna Willis. 2011. Teori-teori Belajar dan Pembelajaran. Jakarta : Erlangga

Dimyati dan Mujiono. 2006. Belajar Dan Pembelajaran. Jakarta : PT Rineka Cipta Djamarah

Endang Sri Astuti, Resminingsih. 2010. Bahan Dasar Untuk Pelayanan Konseling Pada 
Satuan Pendidikan Menengah Jilid I. Jakarta: PT Grasindo.

Fitransyah L, Andy. 2013. Pengaruh Motivasi Belajar Dan Lingkungan Belajar Terhadap Prestasi Belajar Mahasiswa Akuntansi. Skripsi. UPN Veteran Jawa Timur

Khasan, Mas'ud, Abdul Qohar. 1994. Kamus Istilah Pengetahuan Populer. Gresik. CV. Bintang Pelajar.

Moorhead dan Griffin. 2013. Perilaku Organisasi. Jakarta : Salemba Empat

Notoatmodjo, S. 2007. Promosi Kesehatan dan Ilmu Perilaku. Jakarta : Rineka Cipta

Omar, Mohaffyza, and Nazura P. 2015. Dimension of Learning Styles and Student's Academic Achievement". Procedia Social Behaviour Science, 204 (2015) : 172182

Poerwati, Tjahjaning. 2010. Pengaruh Perilaku Belajar Dan Motivasi Terhadap Prestasi Akademik Mahasiswa Akuntansi Di Universitas STIKUBANK (UNISBANK) Semarang. Jurnal Fakultas Ekonomi Universitas STIKUBANK. Vol 8, No 16

Depdiknas. 2008. Kamus Besar Bahasa Indonesia Edisi ke-4. Jakarta: Gramedia Pustaka Utama

Rafiqah, M. Yumansyah, dan Mayasari, S. 2013. Pengaruh Motivasi Belajar Siswa Terhadap Prestasi Belajar Siswa. Jurnal Bimbingan Konseling. Vol. 2, No. 2

Robbins, Stephens. 2015. Perilaku Organisasi.

Jakarta : Salemba Empat

Silalahi, W.R. 2014. Peranan Pendekatan Manajemen Stratejik Dalam Meningkatkan
Kemampuan Pembelajaran Mahasiswa. Jurnal Organisasi dan Manajemen. Vol. 10, No. 2

Slameto. 2010. Belajar dan Faktor-faktor yang Mempengaruhi. Jakarta : Rineka Cipta

Sudaryono, Arief dan Bharata. 2004. Perilaku Belajar di Perguruan Tinggi. Jurnal Akuntansi dan Manajemen. Maret. STIE YKPN. Yogyakarta.

Sugiyono., 2012. Metode Penelitian Kuantitatif, Kualitatif dan R \& D, Bandung : Alfabeta

Sukmadinata, N. Syaodih (2007). Kurikulum dan Pembelajaran. Dalam Ali, M., Ibrahim R, Sukmadinata, N.S., dan Rasjidin, W. (Penyunting). Ilmu dan Aplikasi Pendidikan : Handbook ok. Bandung : Fifupi Press, Halaman 441 sampai 476

Suwarsono, D. 2010. Manajemen Stratejik. Jakarta : Universitas Terbuka

Tafsir, Ahmad. 2008. Ilmu Pendidikan Dalam Perspektif Islam. Bandung: Rosda karya

Tim Pengembangan Ilmu Pendidikan FIP-UPI, 2007, Ilmu dan Aplikasi Pendidikan Seri 3, PT Imperial Bhakti Utama. Bandung

Walgito, Bimo. 2010. Pengantar Psikologi

Umum. Yogyakarta : Penerbit Andi

Wulandari. 2014. Pengaruh Motivasi Belajar, Perilaku Belajar dan Model Pembelajaran Konstruktivisme Terhadap Prestasi Belajar Mahasiswa Kelas Reguler Fakultas Ekonomi dan Bisnis UIN Syarif Hidayatullah Jakarta. Jurnal Bisnis dan Manajemen. Vol. 4 No. 1, April 2014 